\title{
Design of Motorcycle Parking Management for Optimizing Queuing System at Exit Gate (Case Study: Esa Unggul University)
}

\author{
$1^{\text {st }}$ M. Derajat Amperajaya ${ }^{1}, 2^{\text {nd }}$ Taufiqur Rachman ${ }^{1}, 3^{\text {rd }}$ Lius Intan Natalia ${ }^{1}, 4^{\text {th }}$ Arief \\ Suwandi ${ }^{1}$ \\ \{derajat.amperajaya@esaunggul.ac.id ${ }^{1}$, taufiqur.rahman@esaunggul.ac.id ${ }^{1}$ \}
}

Esa Unggul University, Industrial Engineering Department, Faculty of Engineering, Jakarta, Indonesia ${ }^{1}$

\begin{abstract}
Tight competition among University made the University not selected by reputation only but also by the facilities. The parking area is one of the essential facilities to satisfy the demand for parking. Esa Unggul University is the one of University who has their parking area, for car and motorcycle. The long waiting line at servers of parking fee payment can make academicians feel dissatisfaction, especially students as the customers. The long waiting line can be caused by several factors, like the population's size, the queue discipline, the number of servers, and design of the parking area. Even the method of work can be affected by the length of process time and causing the long line. Based on the analyze, the customer arrival rate $(\lambda)$ is 3,493 motorcycle per minute, and the service rate $(\mu)$ is 3,440 motorcycle per minute. The standard time for servicing one customer is 18,885 seconds. Using queuing method and measuring of standard time method, there are three alternative models solutions. Alternative model 1 by adding the operator for checking Vehicle Registration Certificate. Alternative model 2 by building the notice boards and indicator light for showing the cause of queuing. Alternative model 3 by increasing the number of servers. The chosen model is model 2 and reducing the length of process time $40,909 \%$. So the service rate $(\mu)$ up to 5,815 motorcycles per minute.
\end{abstract}

Keywords: Queuing Method, Average Arrival Rate, Average Service Rate, Standard Time

\section{Introduction}

Parking management refers to various policies and programs that result in the more efficient use of parking resources (Giuffrè et al., 2012; Mackowski et al., 2015; Litman, 2016). The development of new technologies in the parking management domain has provided additional alternatives to improve the operation of change-mode parking at facilities such as airports, railroad stations, bus, and rail transit stops (Maccubbin and Hoel, 2000; Kim et al., 2013; Kuran et al., 2015). These technologies aim to minimize the time required to park by simplifying the parking task would benefit the driver and the lot operator (Vianna et al., 2004; Bessghaier et al., 2012; Barone et al., 2013; Zargayouna et al., 2016). Esa Unggul University is the one of University who has their parking area, for car and motorcycle. To manage their parking area, Esa Unggul University has collaborated with Secure Parking Company. Esa 
Unggul University has many academicians, and academicians are allowed to bring a vehicle. It is causing the long waiting line at servers of parking fee payment on exit gate periodically, especially servers of parking fee payment for a motorcycle. So people can feel dissatisfaction, especially students as the customers. This dissatisfaction feeling can make customers giving the poor ratings to service provider, Secure Parking and the University of Esa Unggul as the owner.

The long waiting line can be caused by several factors, like the population's size, the queue discipline, the number of servers, and design of the parking area. Even the method of work can be affected by the length of process time and causing the long line.

The problem is the long waiting line at servers of parking fee payment for a motorcycle on the exit gate in the University of Esa Unggul periodically. Therefore this research is analyzing the queuing system at servers of parking fee payment for motorcycle and the method of work by the operator while servicing customers for reducing the time of customer spends.

This research aims to find out the existing queuing system, to give alternative model solutions, and to choose the best model solution based on alternative models.

\section{Research Method}

The scope of this research is the observations are only on the servers of parking fee payment (exit gate). We collected data from May 9, 2016, to May 15, 2016. Data collecting performed through the observations on the peak time which is at 10.00-13.00 and 15.00-19.00. The method used in this research can be seen in Figure 1. 


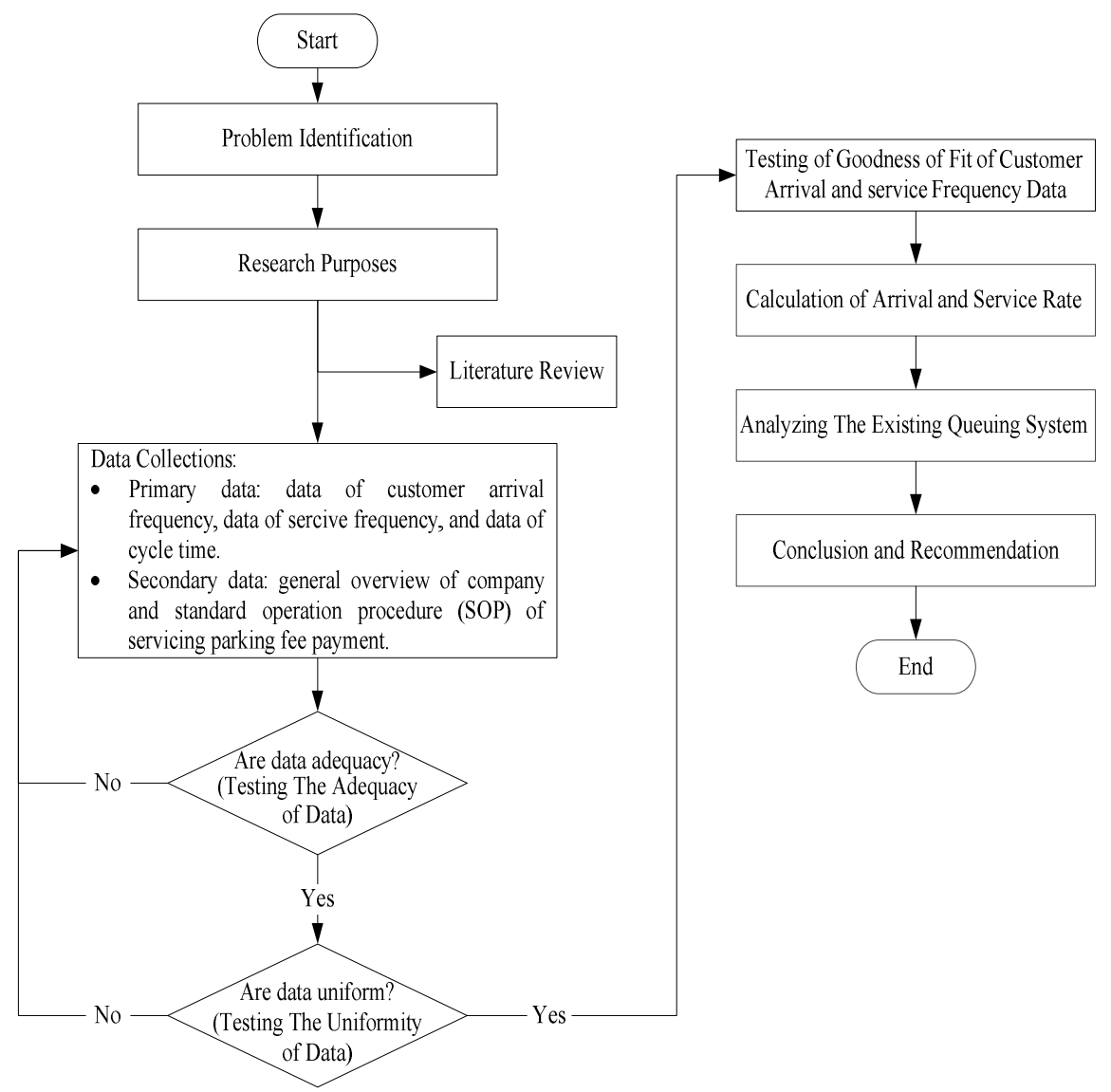

Figure 1. Research method

\section{Results and Discussion}

\subsection{The Observation}

The observations were on the servers of parking fee payment. Based on the observations, customers need to pay a parking fee to leave Esa Unggul University. Data collections divided into two categories, data of customer arrival frequency and data of service frequency. Moreover, it divided into seven subgroups for each category, based on the observations of class schedule and verified by the operator. Data of customer arrival frequency can be seen in Table 1 and data of service frequency can be seen in Table 2.

Table 1. Data Of Customer Arrival Frequency (Motorcycle)

\begin{tabular}{llllllll}
\hline Time & Mon & Tue & Wed & Thu & Fri & Sat & Sun \\
\hline $10.00-11.00$ & 161 & 163 & 157 & 174 & 172 & 143 & 151 \\
$11.00-12.00$ & 179 & 160 & 193 & 168 & 169 & 171 & 155 \\
$12.00-13.00$ & 216 & 189 & 202 & 204 & 186 & 193 & 165
\end{tabular}




\begin{tabular}{llllllll}
\hline Time & Mon & Tue & Wed & Thu & Fri & Sat & Sun \\
\hline $15.00-16.00$ & 249 & 230 & 264 & 259 & 242 & 228 & 221 \\
$16.00-17.00$ & 216 & 221 & 236 & 240 & 218 & 210 & 219 \\
$17.00-18.00$ & 239 & 215 & 235 & 243 & 246 & 251 & 213 \\
$18.00-19.00$ & 253 & 250 & 259 & 238 & 219 & 248 & 235 \\
\hline
\end{tabular}

Table 2. Data of Service Frequency (Motorcycle)

\begin{tabular}{llllllll}
\hline Time & Mon & Tue & Wed & Thu & Fri & Sat & Sun \\
\hline $10.00-11.00$ & 158 & 161 & 154 & 172 & 168 & 140 & 149 \\
$11.00-12.00$ & 175 & 148 & 190 & 163 & 166 & 169 & 153 \\
$12.00-13.00$ & 213 & 194 & 196 & 196 & 186 & 185 & 162 \\
$15.00-16.00$ & 239 & 223 & 257 & 252 & 236 & 225 & 217 \\
$16.00-17.00$ & 215 & 215 & 232 & 233 & 216 & 208 & 212 \\
$17.00-18.00$ & 241 & 220 & 238 & 244 & 249 & 246 & 215 \\
$18.00-19.00$ & 249 & 244 & 257 & 241 & 214 & 242 & 235 \\
\hline
\end{tabular}

\subsection{Testing The Adequacy of Data of Customer Arrival Frequency}

To test the adequacy of data of customer arrival frequency using equation (1).

$$
N^{\prime}=\left(\frac{k / s \sqrt{N \times \sum X_{i}^{2}-\left(\sum X_{i}\right)^{2}}}{\sum X_{t}}\right)^{2}
$$

with,

$\mathrm{k}=$ confidence level

$=99 \% \approx 3$

$=95 \% \approx 2$

$\mathrm{s}=$ margin of error

$\mathrm{N}=$ the number of data collections

$\mathrm{N}^{\prime}=$ theoretically data size

$\mathrm{X}_{\mathrm{i}}=$ the value of observation $\mathrm{i}$

The $\mathrm{N}^{\prime}=43,324 \approx 43$ data. So data collections can be analyzed because $\mathrm{N}^{\prime}<\mathrm{N}(43<49)$.

\subsection{Testing The Uniformity of Data of Customer Arrival Frequency}

The result of testing the uniformity of data of customer arrival frequency can be seen in Figure 2. Based on the graph, data of customer arrival frequency is uniform. 


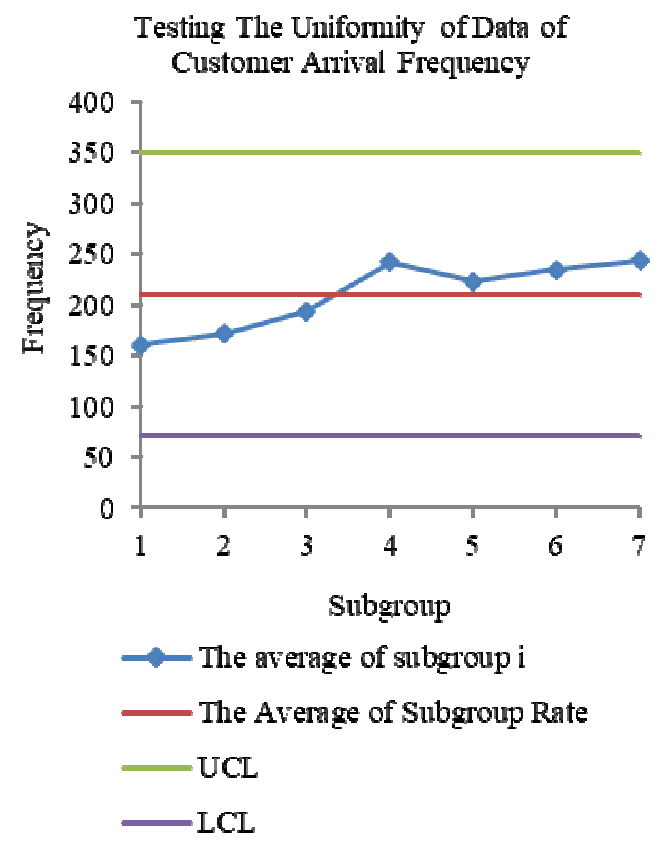

Figure 2. Graph testing the uniformity of data of customer arrival frequency

\subsection{Testing The Adequacy of Data of Service Frequency}

To testing the adequacy of data of service frequency using equation (1), and the N' = $44,869 \approx 45$ data. So data collections can be analyzed because $\mathrm{N}^{i}<\mathrm{N}(45<49)$.

\subsection{Testing The Uniformity of Data of Service Frequency}

The result of testing the uniformity of data of service frequency can be seen in Figure 3 . Based on the graph, data of service frequency is uniform. 


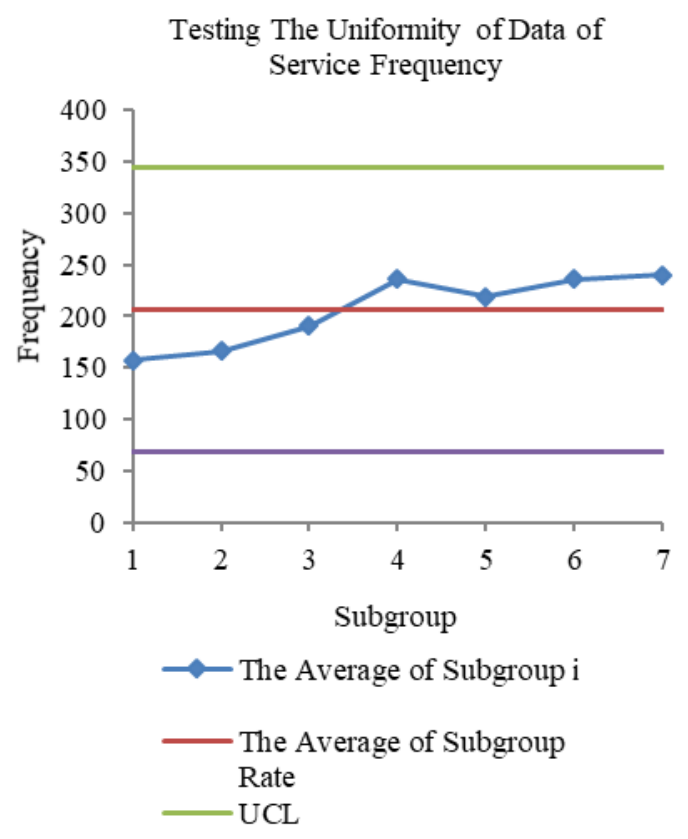

Figure 3. Graph testing the uniformity of data of service frequency

\subsection{Measuring Goodness of Fit of Customer Arrival Frequency Data}

The measurement of goodness of fit of customer arrival frequency data using chi-square method. Based on the measurement, customer arrival frequency data is Poisson.

\subsection{Measuring Goodness of Fit of Service Frequency Data}

The measurement of goodness of fit of service frequency data using the chi-square method. Based on the measurement, service frequency data is exponential.

\subsection{Calculation of Arrival Rate}

The measurement of goodness of fit of service frequency data using the chi-square method. Based on the measurement, service frequency data is exponential.

$$
\overline{\bar{X}}=\frac{\sum \bar{X}_{L}}{n}
$$

with,

$\bar{X} \quad=$ average of subgroup rate

$\sum \bar{X}_{l}=$ average of data collections

$\mathrm{n}=$ the number of subgroups

The arrival rate $(\lambda)$ is 209,551 motorcycle per hour or 3,493 motorcycles per minute.

\subsection{Calculation of Service Rate}


The calculation of service rate also using equation (2). The service rate $(\mu)$ is 206,388 motorcycle per hour or 3,440 motorcycles per minute. So the average time for servicing customers is 0,291 minutes per motorcycle or 17,46 seconds per motorcycle.

\section{Identification of Existing Queuing System}

Design of existing queuing system is (M/M/2):(GD/ / ) or also known as Model B:(M/M/S).

1) The Arrival Source

There are two parking locations in system, front-side parking area and back-side parking area. The distance of front-side parking area to servers is 10,4 meters, and the distance of back-side parking area to servers is 172,58 meters.

\section{2) The Servicing System}

Design of servicing system is single phase-multi servers. There are two servers of parking fee payment. Moreover, the queue discipline is First Come First Serve (FCFS).

\section{3) The Service Method}

The service has started by taking ticket by customers. Then the customers are allowed to get in the parking area. The parking ticket is the evidence that customers hired the parking area. When the customers come, they can see an information board that gives information about the parking fee. The parking fee is $\mathrm{Rp} 1500$ for one entrance.

When customers want to leave Esa Unggul University, they need to pay the parking fee. The service of parking fee payment has started from customer leave the parking area and go to the server. At the server, customers give the ticket, Vehicle Registration Certificate (VRC), and pay the parking fee to the operator. After the operator scanning the barcode of the ticket and checking the VRC, the customers are allowed to leave.

\section{4) Operator Activity}

Operator activity is the actual activity by the operator while servicing customers. The operator can be affected by the length of process time. Based on the observations, the work elements in one work cycle for 22 seconds can be seen in Table 3 .

Table 3. The Work Elements in One Work Cycle For 22 Seconds

\begin{tabular}{|c|c|c|c|}
\hline Operator & Duration (sec) & Customer & Duration (sec) \\
\hline $\begin{array}{l}\text { Typing the number of the } \\
\text { license plate on the } \\
\text { computer }\end{array}$ & 2 & Waiting & 2 \\
\hline $\begin{array}{l}\text { Receiving a ticket and } \\
\text { the cash, then checking } \\
\text { the cash. }\end{array}$ & 1 & $\begin{array}{l}\text { Giving the ticket and } \\
\text { pay the fee }\end{array}$ & 1 \\
\hline Scanning barcode ticket & 2 & Waiting & 2 \\
\hline $\begin{array}{l}\text { Checking license plate, } \\
\text { the type, and color of } \\
\text { motorcycle based on the } \\
\text { photo in the computer }\end{array}$ & 1 & Waiting & 1 \\
\hline $\begin{array}{l}\text { Taking money for the } \\
\text { change }\end{array}$ & 2 & Waiting & 2 \\
\hline Asking for VRC & 1 & Listening & 1 \\
\hline
\end{tabular}




\begin{tabular}{|c|c|c|c|}
\hline Operator & Duration $(\mathrm{sec})$ & Customer & Duration (sec) \\
\hline Waiting & 4 & Taking VRC & 4 \\
\hline Checking the VRC & 2 & Giving the VRC & 2 \\
\hline $\begin{array}{l}\text { Giving the change and } \\
\text { VRC }\end{array}$ & 1 & $\begin{array}{l}\text { Receiving the change } \\
\text { and VRC }\end{array}$ & 1 \\
\hline $\begin{array}{l}\text { Open the portal by } \\
\text { pressing enter }\end{array}$ & 1 & Waiting & 1 \\
\hline Waiting & 5 & Preparing to go & 5 \\
\hline Total & 22 & Total & 22 \\
\hline
\end{tabular}

Source: Observations

For those reasons, then need to know the standard time for servicing customers. The data of cycle time measured by a stopwatch. It divided into seven subgroups, and ten times observations for each subgroup.

a) Testing the adequacy of data of cycle time

To test the adequacy of data of cycle time using equation (1), and the $N^{\prime}=37,722 \approx 38$ data. So data collections can be analyzed because $\mathrm{N}^{\prime}<\mathrm{N}(38<70)$.

b) Testing the uniformity of data of cycle time

The result of testing the uniformity of data of cycle time can be seen in Figure 4. Based on the graph, data of cycle time is uniform.

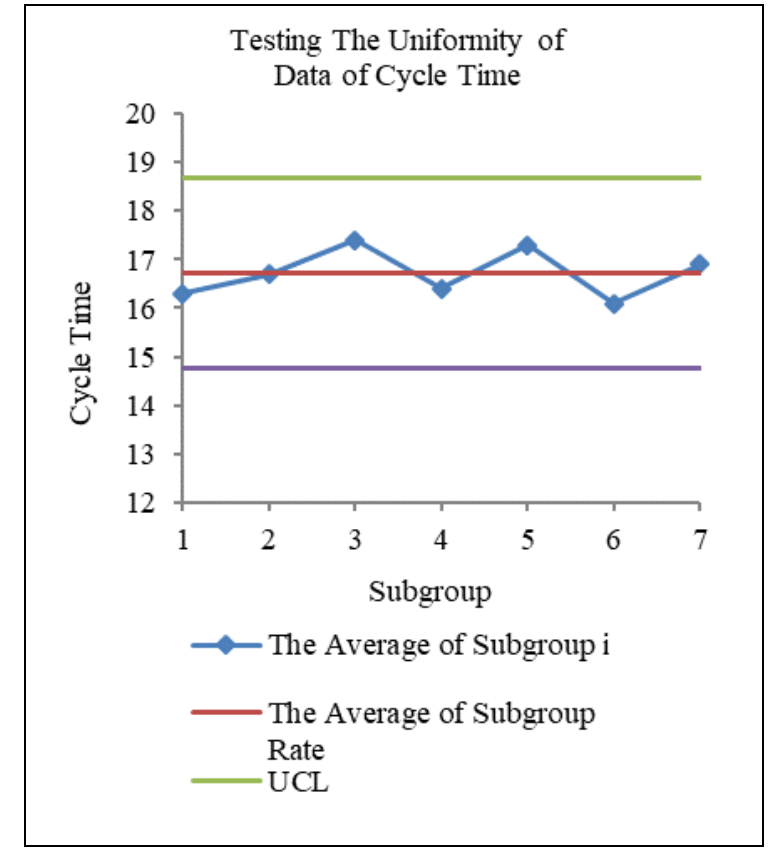

Figure 4. Graph testing the uniformity of data of cycle time

c) Determining Adjustment Factor

The adjustment factor had determined using an objective method. Assumed the operator's service speed is normal, then adjustment factor 1 (AF1) value is 1 . Moreover, the adjustment factor by difficulty (AF2) is 1,07. So a total of adjustment factor is the multiplication of AF1 and $\mathrm{AF} 2=1 \times 1,07=1,07$. 
d) Determining Allowance Factor

The allowance factor had determined based on affecting factors. So the allowance is $5,5 \%$. 0,055 .

e) Calculation of Standard Time

The calculation of cycle time $\left(\mathrm{C}_{\mathrm{t}}\right)$ using equation (3).

$$
C_{t}=\frac{\sum \overline{X_{l}}}{n}
$$
(4).

The cycle time is 16,729 seconds. Then calculating the normal time $\left(\mathrm{N}_{\mathrm{t}}\right)$ using equation

$$
N_{t}=C_{t} \times \text { adjustment factor }
$$

So the normal time is 17,900 seconds. And then calculating the standard time $\left(\mathrm{S}_{\mathrm{t}}\right)$ using equation (5).

$$
S_{t}=N_{t} \times(1+\text { allowance })
$$

So the standard time is 18,885 seconds.

\section{Alternative Model 1}

This model is suggesting to comply with the procedure. Based on the procedure, there is VRC checker to checking the VRC since the waiting line started. So the operator at the server does not need to check the VRC.

\footnotetext{
Alternative Model 2

This model is suggesting to build the notice boards at the parking area and server (portal), an indicator light for showing the cause of queuing. The indicator light consists of 2 lamps, red and yellow. The red lamp means the queuing caused by system error or operator. Moreover, the yellow lamp means the queuing caused by the customer. The notice board used to notify the customer for preparing their ticket, VRC, and money since at parking area, keep riding in line and put the change and VRC back after passing the portal. Design of the notice board at the parking area can be seen in Figure 5.
} 


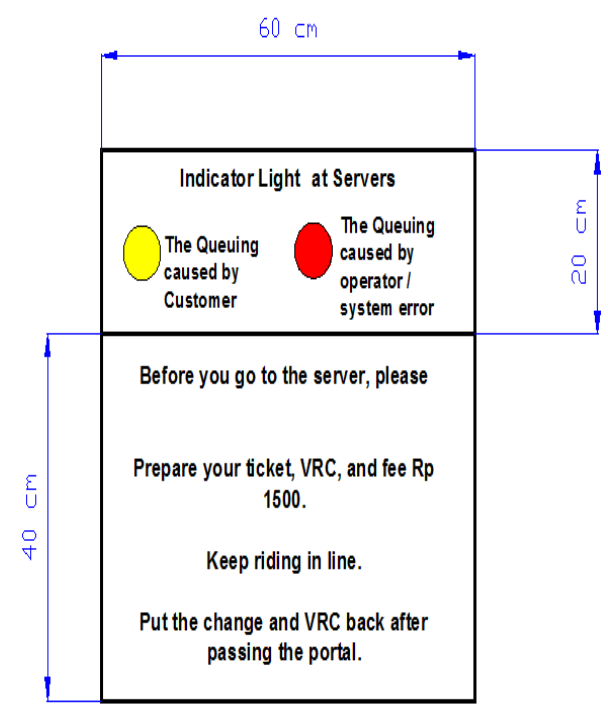

Figure 5. Design of notice board at parking area

The notice board has two sides, and the truss is \pm 2 meters height. Design of the notice board at portal can be seen in Figure 6.

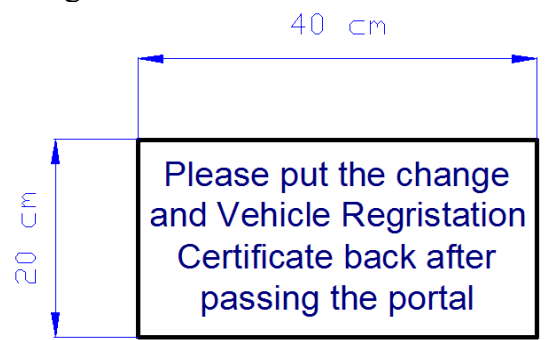

Figure 6. Design of notice board at portal

\section{Alternative Model 3}

This model is suggesting to increase the number of servers. So there are three servers. Servers 1 is at the front-side parking area. Server 2 and server 3 are at the back-side parking area. The location of server 1 can be seen in Figure 7. 


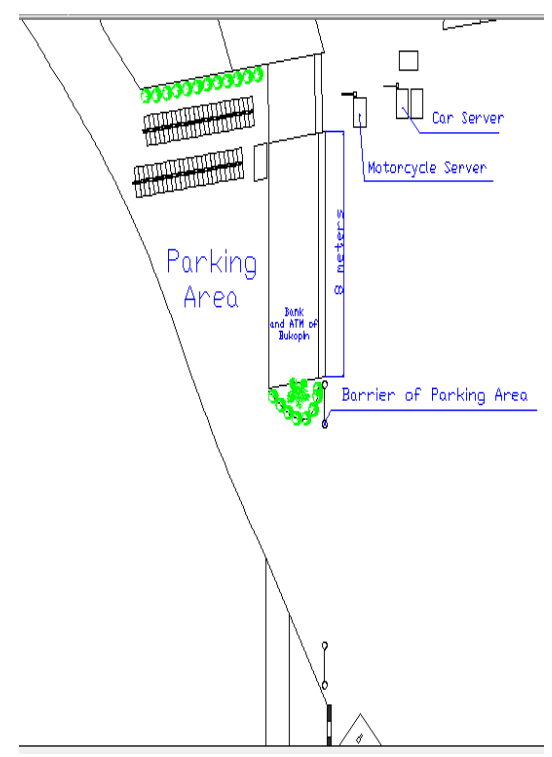

Figure 7. Location of server 1

The location of server 2 and server 3 can be seen in Figure 8.

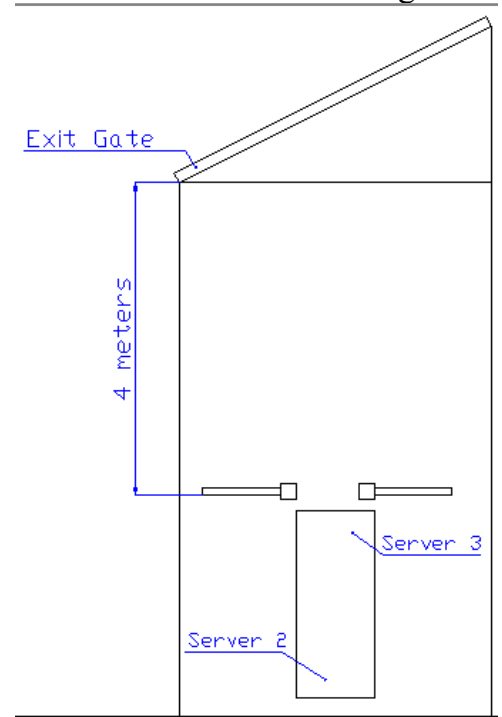

Figure 8. Location of server 2 and server 3

\section{Comparison of Alternative Models}

The comparison of alternative models by theoretical calculation can be seen in Table 4 .

Table 4. Comparing Models by the Calculation Results 


\begin{tabular}{|c|c|c|c|c|}
\hline Results & 1 & 2 & 3 & Model \\
\hline The & 2 & 2 & 3 & 2 \\
\hline $\begin{array}{l}\text { number of } \\
\text { servers }\end{array}$ & servers & servers & servers & servers \\
\hline Service rate & $5,040 \approx$ & $5,815 \approx$ & $3,440 \approx$ & $3,440 \approx$ \\
\hline$(\mu)$ & $\begin{array}{l}6 \text { motor- } \\
\text { cycle } \\
\text { per } \\
\text { minute }\end{array}$ & $\begin{array}{l}6 \text { motor- } \\
\text { cycle } \\
\text { per } \\
\text { minute }\end{array}$ & $\begin{array}{l}4 \text { motor- } \\
\text { cycle } \\
\text { per } \\
\text { minute }\end{array}$ & $\begin{array}{l}4 \text { motor- } \\
\text { cycle } \\
\text { per } \\
\text { minute }\end{array}$ \\
\hline Cycle time & $15 \mathrm{sec}$ & $13 \mathrm{sec}$ & $\begin{array}{l}16,729 \\
\approx 17 \mathrm{sec}\end{array}$ & $\begin{array}{l}16,729 \\
\approx 17 \mathrm{sec}\end{array}$ \\
\hline $\begin{array}{l}\text { The } \\
\text { probability } \\
\text { that there } \\
\text { are no } \\
\text { customer in } \\
\text { the system } \\
\left(\mathrm{P}_{0}\right)\end{array}$ & $48,50 \%$ & $53,81 \%$ & $35,80 \%$ & $32,70 \%$ \\
\hline Average & $0,788 \approx$ & $0,661 \approx$ & $1,063 \approx$ & $1,368 \approx$ \\
\hline $\begin{array}{l}\text { number of } \\
\text { customers } \\
\text { in the } \\
\text { system (Ls) }\end{array}$ & $\begin{array}{l}1 \text { motor- } \\
\text { cycle }\end{array}$ & $\begin{array}{l}1 \text { motor- } \\
\text { cycle }\end{array}$ & $\begin{array}{l}2 \text { motor- } \\
\text { cycle }\end{array}$ & $\begin{array}{l}2 \text { motor- } \\
\text { cycle }\end{array}$ \\
\hline $\begin{array}{l}\text { Average } \\
\text { time } \\
\text { customer } \\
\text { spends in } \\
\text { the system } \\
\text { (Ws) }\end{array}$ & $\begin{array}{l}13,536 \\
\text { sec }\end{array}$ & $\begin{array}{l}11,354 \\
\text { sec }\end{array}$ & $\begin{array}{l}18,24 \\
\sec \end{array}$ & $\begin{array}{l}23,52 \\
\sec \end{array}$ \\
\hline $\begin{array}{l}\text { Average } \\
\text { number of } \\
\text { customers } \\
\text { in the } \\
\text { queue (Lq) }\end{array}$ & $\begin{array}{l}0,095 \approx \\
1 \text { motor- } \\
\text { cycle }\end{array}$ & $\begin{array}{l}0,06 \approx 1 \\
\text { motor- } \\
\text { cycle }\end{array}$ & $\begin{array}{l}0,047 \approx \\
1 \text { motor- } \\
\text { cycle }\end{array}$ & $\begin{array}{l}0,353 \approx \\
1 \text { motor- } \\
\text { cycle }\end{array}$ \\
\hline $\begin{array}{l}\text { Average } \\
\text { time } \\
\text { customer } \\
\text { spends in } \\
\text { the queue } \\
(\mathrm{Wq})\end{array}$ & $\begin{array}{l}1,632 \\
\sec \end{array}$ & $\begin{array}{l}1,031 \\
\sec \end{array}$ & $0,78 \mathrm{sec}$ & $6,06 \mathrm{sec}$ \\
\hline
\end{tabular}

\section{Conclusion}

The conclusions of this research are:

1) The existing queuing system

a) Customer arrival rate $(\lambda) 3,493$ motorcycle per minute and service rate $(\mu) 3,440$ motorcycle per minute.

b) The standard time for servicing one customer is $18,885 \mathrm{sec}$.

c) The probability that there are no customer in the system $\left(\mathrm{P}_{0}\right)=32,7 \%$, average number of customers in the system $\left(L_{s}\right)=1,368 \approx 2$ motorcycle, average time 
customer spends in the system $\left(\mathrm{W}_{\mathrm{s}}\right)=23,52 \mathrm{sec}$, average number of customers in the queue $\left(\mathrm{L}_{\mathrm{q}}\right)=0,353 \approx 1$ motorcycle and average time customer spends in the queue $\left(\mathrm{W}_{\mathrm{q}}\right)=6,06 \mathrm{sec}$.

2) There are 3 alternative model solutions

a) Alternative model 1, add the operator for checking VRC.

b) Alternative model 2, build the notice boards and indicator light for showing the cause of queuing.

c) Alternative model 3, increase the number of servers.

3) The chosen model as the solution is model 2, with:

a) Reducing the length of process time $40,909 \%$.

b) The service rate $(\mu)$ up to 5,815 motorcycles per minute.

c) The probability that there are no customer in the system $\left(\mathrm{P}_{0}\right)=53,81 \%$, average number of customers in the system $\left(\mathrm{L}_{\mathrm{s}}\right)=0,661 \approx 1$ motorcycle, average time customer spends in the system $\left(\mathrm{W}_{\mathrm{s}}\right)=11,354 \mathrm{sec}$, average number of customers in the queue $\left(\mathrm{L}_{\mathrm{q}}\right)=0,060 \approx 1$ motorcycle, and average time customer spends in the queue $\left(\mathrm{W}_{\mathrm{q}}\right)=1,031 \mathrm{sec}$.

Based on the results and discussion section, the recommendations for future research are:

1) May implementing/measuring alternative model solutions.

2) May analyzing the speed of operators.

3) May comparing model solution to another parking company.

4) May considering the cost.

Acknowledgements. This paper in conjunction with the ICRI 2018 in Jakarta, Indonesia.

\section{References}

[1] Barone, R. E., Giuffrè, T., Siniscalchi, S. M., Morgano, M. A., and Tesoriere, G. (2013). Architecture for parking management in smart cities. IET Intelligent Transport Systems, 8(5): 445452.

[2] Bessghaier, N., Zargayouna, M., and Balbo, F. (2012, September). Management of urban parking: an agent-based approach. In International Conference on Artificial Intelligence: Methodology, Systems, and Applications, pp. 276-285. Springer, Berlin, Heidelberg.

[3] Giuffrè, T., Siniscalchi, S. M., and Tesoriere, G. (2012). A novel architecture of parking management for smart cities. Procedia-Social and Behavioral Sciences, 53: 16-28.

[4] Kim, M. S., Lee, D. H., and Kim, K. N. J. (2013, June). A study on the NFC-based mobile parking management system. In Information Science and Applications (ICISA) 2013 International Conference, pp. 1-5. IEEE.

[5] Kuran, M. Ş., Viana, A. C., Iannone, L., Kofman, D., Mermoud, G., and Vasseur, J. P. (2015). A smart parking lot management system for scheduling the recharging of electric vehicles. IEEE Transactions on Smart Grid, 6(6): 2942-2953.

[6] Litman, T. (2016). Parking management. Victoria Transport Policy Institute.

[7] Maccubbin, R. P., and Hoel, L. A. (2000). Evaluating ITS parking management strategies: A systems approach (No. UVA/29472/CE00/102,). Charlottesville, VA: University of Virginia.

[8] Mackowski, D., Bai, Y., and Ouyang, Y. (2015). Parking space management via dynamic performance-based pricing. Transportation Research Procedia, 7: 170-191. 
[9] Vianna, M. M. B., da Silva Portugal, L., and Balassiano, R. (2004). Intelligent transportation systems and parking management: implementation potential in a Brazilian city. Cities, 21(2): 137148.

[10] Zargayouna, M., Balbo, F., and Ndiaye, K. (2016). Generic model for resource allocation in transportation. Application to urban parking management. Transportation Research Part C: Emerging Technologies, 71: 538-554. 